Section Editor

Mitchell S.V. Elkind,

MD, MS

\title{
Teaching NeuroImages: \\ Facial diplegia due to neuroborreliosis
}

Jamie Campbell, MB

John McNamee, MB

Peter Flynn, MB

Gavin McDonnell, MD

Correspondence to

Dr. Campbell:

jcampbell@talk21.com

\section{Figure 1 MRI brain shows multiple cranial nerve involvement}

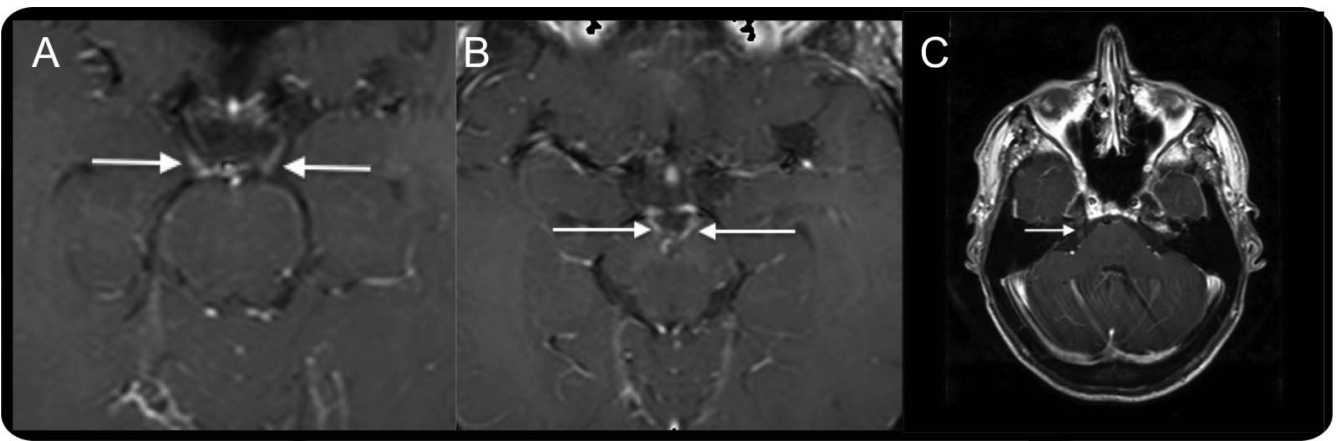

(A) Axial T1-weighted image postcontrast shows enhancement of the cisternal segments of the oculomotor nerves bilaterally (white arrows). (B) Axial T1-weighted image postcontrast demonstrates enhancement of the interpeduncular portions of the oculomotor nerves bilaterally (white arrows). (C) Axial T1-weighted image postcontrast demonstrates enhancement of the cisternal portion of the right trigeminal nerve (white arrow).

Figure $2 \quad$ MRI brain shows multiple cranial nerve involvement

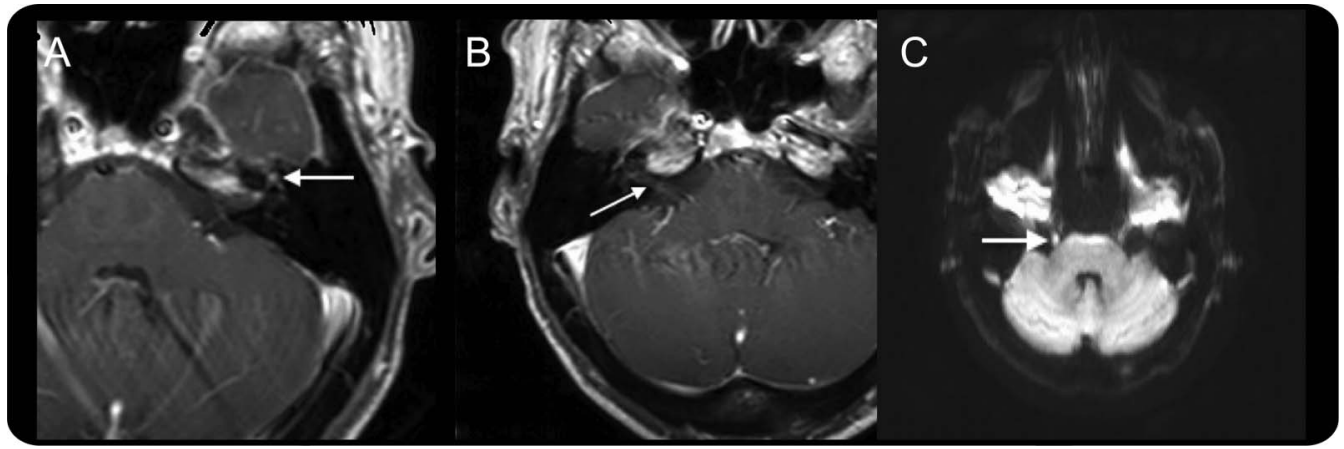

(A) Axial T1-weighted image postcontrast demonstrates enhancement of the intracanilicular, labyrinthine, and proximal tympanic segments of the left facial nerve. The first genu is clearly visible (white arrow). (B) Axial T1-weighted image postcontrast demonstrates enhancement of the cisternal and intracanilicular portions of the right facial nerve (white arrow). (C) Axial diffusion-weighted imaging (B1000) demonstrates restricted diffusion within the cisternal segment of the right trigeminal nerve.

A 39-year-old man presented with progressive facial diplegia and mild headache. He reported a self-limited migratory rash 3 weeks previously following a walk in Castlewellan Forest Park in Northern Ireland.

Brain MRI revealed contrast enhancement of cranial nerves III, V, and VII (figures 1 and 2). CSF revealed 356 lymphocytes $/ \mu \mathrm{L}$, protein $2.64 \mathrm{~g} / \mathrm{L}$, and normal glucose. Serology was positive for Borrelia antibodies. Clinical manifestations of neuroborreliosis may include meningitis, cranial neuropathies, and radiculoneuritis. MRI brain can show enhancement of multiple cranial nerves. ${ }^{1}$ This patient was symptomatic only of facial nerve involvement. Treatment is with oral doxycycline or IV cephalosporin. Our
Download teaching slides: www.neurology.org

From the Department of Neurology, Belfast Health and Social Care Trust (J.C., G.M.), and the Department of Neuroradiology (J.M., P.F.), Royal Victoria Hospital, Belfast, UK.

Go to Neurology.org for full disclosures. Funding information and disclosures deemed relevant by the authors, if any, are provided at the end of the article. 
patient made a full recovery following the completion of a course of IV ceftriaxone. ${ }^{2}$

\section{AUTHOR CONTRIBUTIONS}

J. Campbell: design/conceptualization of study and revising manuscript. J. McNamee: conceptualization of study and revising manuscript. P. Flynn: revising manuscript. G. McDonnell: conceptualization of study and revising manuscript.

\section{STUDY FUNDING}

No targeted funding reported.

\section{DISCLOSURE}

The authors report no disclosures relevant to the manuscript. Go to Neurology.org for full disclosures.

\section{REFERENCES}

1. Agarwal R, Sze G. Neuro-Lyme disease: MR imaging findings. Radiology 2009;253:167-173.

2. Ljostad U, Skogvoll E, Eikeland R, et al. Oral doxycycline versus intravenous ceftriaxone for European Lyme neuroborreliosis: a multicentre, non-inferiority, double blind, randomised trial. Lancet Neurol 2008;7:690-695. 


\section{Neurology}

\section{Teaching NeuroImages: Facial diplegia due to neuroborreliosis}

Jamie Campbell, John McNamee, Peter Flynn, et al.

Neurology 2014;82;e16-e17

DOI 10.1212/WNL.0000000000000018

This information is current as of January 13, 2014

Updated Information \&

Services

Supplementary Material

References

Subspecialty Collections

Permissions \& Licensing

Reprints including high resolution figures, can be found at: http://n.neurology.org/content/82/2/e16.full

Supplementary material can be found at: http://n.neurology.org/content/suppl/2014/01/11/82.2.e16.DC1

This article cites 2 articles, 0 of which you can access for free at: http://n.neurology.org/content/82/2/e16.full\#ref-list-1

This article, along with others on similar topics, appears in the following collection(s):

\section{All Headache}

http://n.neurology.org/cgi/collection/all_headache

MRI

http://n.neurology.org/cgi/collection/mri

Parasitic infections

http://n.neurology.org/cgi/collection/parasitic_infections

Information about reproducing this article in parts (figures,tables) or in its entirety can be found online at:

http://www.neurology.org/about/about_the_journal\#permissions

Information about ordering reprints can be found online:

http://n.neurology.org/subscribers/advertise

Neurology ${ }^{\circledR}$ is the official journal of the American Academy of Neurology. Published continuously since 1951, it is now a weekly with 48 issues per year. Copyright (O 2014 American Academy of Neurology. All rights reserved. Print ISSN: 0028-3878. Online ISSN: 1526-632X.

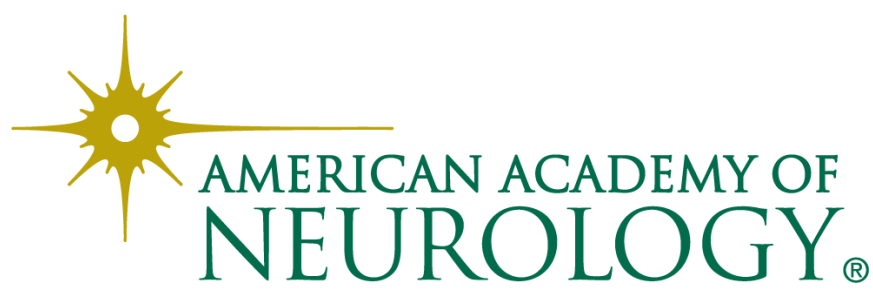

